\title{
Book Review "Cultural Finance: A World Map of Risk, Time and Money" by Thorsten Hens, Marc Oliver Rieger, and Mei Wang. Singapore: World Scientific Publishing Co. Pte. Ltd., 2020; ISBN 9789811221958
}

\author{
Anh Ngoc Quang Huynh ${ }^{1}$ and Toan Luu Duc Huynh $1,2,3, *$ (D) \\ 1 School of Banking, University of Economics Ho Chi Minh City, Ho Chi Minh City 70000, Vietnam; \\ anhhnq@ueh.edu.vn \\ 2 WHU—Otto Beisheim School of Management, 56179 Vallendar, Germany \\ 3 IPAG Business School, 75006 Paris, France \\ * Correspondence: toanhld@ueh.edu.vn
}

Citation: Huynh, Anh Ngoc Quang, and Toan Luu Duc Huynh. 2021. Book Review "Cultural Finance: A World Map of Risk, Time and Money" by Thorsten Hens, Marc Oliver Rieger, and Mei Wang. Singapore: World Scientific Publishing Co. Pte. Ltd., 2020; ISBN 9789811221958. Journal of Risk and Financial Management 14: 262. https:// doi.org/10.3390/jrfm14060262

Academic Editor: Michael McAleer

Received: 30 May 2021

Accepted: 4 June 2021

Published: 10 June 2021

Publisher's Note: MDPI stays neutral with regard to jurisdictional claims in published maps and institutional affiliations.

Copyright: (c) 2021 by the authors. Licensee MDPI, Basel, Switzerland. This article is an open access article distributed under the terms and conditions of the Creative Commons Attribution (CC BY) license (https:// creativecommons.org/licenses/by/ $4.0 /)$.
Abstract: This is book review of "Cultural Finance, A World Map of Risk, Time and Money" edited by Thorsten Hens, Marc Oliver Rieger and Mei Wang. This book review's focus point is on how "Cultural Finance, A World Map of Risk, Time and Money" develops, based on the book's content, in the current studies of prospect theory preferences in 53 different countries. The book review starts with a literature review on studied research in "Cultural Finance, A World Map of Risk, Time and Money", follows with short summaries of each chapter, and finally sums up its practical implication. This book greatly demonstrates the greatest care and thoroughness regarding the growth of cultural finance.

Keywords: cultural finance; money; risk; time

\section{Introduction}

The content of "Cultural Finance, A World Map of Risk, Time and Money" regards an emerging field called "cultural finance" where behavioral finance is driven by individual biases, and risk and time preferences in different cultures. It has been proven that risk and time are central to the understanding of economics. Therefore, the prospect theory used is the behavioral model of decisions under risk by Kahneman and Tversky (1979). Data is collected using a global-scaled survey called INTRA (International Test on Risk Attitudes) through one of the authors' worldwide network of colleagues in 53 different countries from 2007 to 2012 all over the world. This overall concept sharpens how cultural finance works in our current literature review.

\section{Book's Contents}

The first section highlights the time dimension. The key findings of few first chapters are whether people from different countries with distinct cultural backgrounds have different financial time preferences.

This book tapped into the global-scale survey perspective. First, all 53 surveyed countries manifest hyperbolic discounting patterns, and it is shown that heterogeneity tends to be higher in shorter time horizons, which appears to be consistent to the pattern reviewed by Frederick et al. (2002). Second, more developed countries have less time discounting and culturally closer countries tend to have more similar levels of time discounting. In addition, other described cultural characteristics including Gross Domestic Product, inflation, and economic growth rate by cultural perspectives (Hofstede 1991) considerably contribute to the difference in time discounting. For instance, higher levels of Uncertainty Avoidance are linked to more hyperbolic discounting while higher levels of individualism and Long-term 
Orientation are linked to a greater willingness to wait for a larger payoff. Finally, nations, which tend to wait for higher returns, tend to have a faster rate of time measured from field research.

With regards to how cultural value correlates with time preferences, there are three important cultural dimensions discussed regarding the relationships with time preferences: Individualism, Uncertainty Avoidance and Long Term Orientation. However, all three of these dimensions appear to have no relationship with time preferences. Theoretical predictions conducted from the effects of wealth, growth rate, and financial market accessibility are first derived based on a two-period intertemporal problem, then cross-country data on time discounting (Wang et al. 2016) took place to test whether those predictions held. The results show that participants from nations with higher economic condition, proxied by GDP per capita, and the lower level of economic condition are more willing to wait to earn better returns. In addition, the inflation rate has only one effect on the one-month waiting tendency instead of longer time periods. Furthermore, the result, which shows that a higher growth rate induces higher discounting, confirms the predicted effects of proposed model. Lastly, when it comes to free market access, the conducted results support the authors' model of time preferences without access to financial markets. However, there are two remaining points that can be further discussed, specifically the lack of monetary incentive in the survey and the impossibility in extricating the sophisticated interactions between time preferences and all three economic factors.

When it comes to refugees versus university students, Syrian refugees have significantly lower levels of patience and purchasing power compared to participating university students. The results show that the difference has nearly nothing to do with cultural distinctions but is more driven by self-selection. On the other hand, Deole and Rieger (2020) shed more light on the topic when comparing time preferences of Chinese students in China and those abroad. The results reveal that students studying in foreign countries are more patient than domestic Chinese students. The possible explanation is that migration motifs and self-selection play an important role. However, living conditions of refuges and students is also a factor of the disparity.

The second dimension worth-mentioning is risk. To analyze if there is an international distinction between risk preferences and its correlation with economic condition and cultural dimensions, a comprehensive survey of attitudes towards risk in 53 nations was used. The diversity of nations allows researchers to determine whether the cross-country variation of risk attitudes exhibits systematic pattern and can be foreseen using cultural factors. In addition, by following a core notion of the well-known theoretical framework, the Prospect Theory, in differentiating risk attitudes in the gain and loss domains, the authors' main findings can be summarized as follows: participants from wealthier nations (based on GDP per capita) are more risk averse in gains but tend to be more risk seeking in losses. Higher uncertainty avoidance shows the correspondence that people are likely to be more risk averse in gains but more risk seeking in losses. Finally, there is an observable difference in gender. In particular, men are less risk averse in gains in general. The survey, which can be considered as the largest international reference, has pointed out coherent effects from both economic and cultural factors on risk preferences as earlier discussed by the Hofstede dimensions. In addition, beside the major effect of culture on risk preference, risk aversion in gains and risk-seeking behavior in losses are two globally essential features of risk behavior. Based on these findings, several applications have been conducted, including the works of Breuer et al. (2012) and Rieger and Wang (2012).

It is important to explain the mechanism of loss aversion and risk aversion. Overall, loss aversion is related to risk aversion, but they differ from each other. Loss aversion has been a powerful tool to explain decision-making biases that contradict basic anticipated utility theory including the endowment effect, the status quo bias, and buying-selling price gaps (Camerer 2000, 2005). However, the degree of loss aversion generally varies (Schmidt and Traub 2002; Vendrik and Woltjer 2007; Tanaka et al. 2010) and it mainly depends on psychological factors and emotion (Ariely et al. 2005; Lerner et al. 2004; 
De Martino et al. 2010; Novemsky and Kahneman 2005; Sokol-Hessner et al. 2009). It has been proven that loss aversion can be simultaneously affected by both emotion regulation and cultural factors. This chapter combines both streams of literature to test if systematic and predictable cultural differences exist in loss aversion.

Concomitantly, we also observe differences in genders. Gender plays a significant role in any culture, and the gender differences that impact risk and time preferences are no exception. According to Eagly (1987), the distinction in preferences between men and women tend to be smaller when women experience more freedom and equality. However, the opposite appears to be true based on the works of Falk and Hermle (2018) and Hardelauf (2019). In addition, regarding loss aversion, it has been discovered that female subjects have a stronger trend. On the other hand, the gender effect is not robust and conflicting in several research.

The last section which should be highlighted is financial markets. First and foremost, we summarize the perspective of loss aversion. Benartzi and Thaler (1995) and Barberis and Huang (2008) have conducted a myopic loss aversion, which aided this book's authors in predicting distinction in time discounting among different nations causing different equity premiums. Their results recommend that differences in time discounting could justify some of the differences in equity premiums. It is claimed that differences in time discounting are not the only explanation for differences in equity premiums. Thus, finding results can provide some encouraging empirical data, indicating that this model can explain the equity premium conundrum at least in part and can also be used to provide empirical evidence for other market behavioral finance issues that are otherwise difficult to investigate. Second, ambiguity aversion will be followed. Ambiguity aversion has been proposed as a possible explanation for large equity premia. In their study, they gathered empirical data on equity premia and ambiguity aversion on a cross-country basis and found that ambiguity aversion increases the equity premium. Finally, there is a link between one of Hofstede's cultural characteristics, uncertainty avoidance, and the equity premium, which appears to act through ambiguity aversion as a mediator. Concomitantly, one of the most well-known puzzles in finance is the equity risk premium. It was firstly discussed by Mehra and Prescott (1985) when they found that during the previous 90-year period, the U.S. stock market had witnessed much larger historical average returns compared to the average returns of short-term debt. The only possible given explanation was by a much larger level of risk aversion. Following this finding is extensive research trying to provide other possible explanations regarding this puzzle, and two of the most convincing theories are extracted from work on myopic loss aversion Benartzi and Thaler (1995); Barberis and Huang (2006) and work on ambiguity aversion Chen and Epstein (2003); Barillas et al. (2009); Gollier (2011). Most surveyed countries are affected by both ambiguity aversion and information uncertainty. In addition, countries that have low degree of ambiguity aversion tend to have a stronger effect of information uncertainty. It is very important to explore a cross-country analysis regarding behavioral foundations of corporate dividend policy. A panel analysis has been conducted across 43,000 firm-years in 29 countries and it shows a connection between dividends and patience, loss aversion, and ambiguity aversion. Many research papers had been working on the same topic including Brockman and Unlu (2009) (dividend payouts), Drobetz et al. (2010) (cash holdings), and Acharya et al. (2011) (capital structure). Nevertheless, those papers have failed to explain why they rely on firm-level or country-level clustering. Based on finding results using smaller standard errors, the authors conclude that patience, loss aversion, and ambiguity aversion are more significant with firm-clustered standard errors. In addition, those factors all have high practicality for the determination of cross-country differences. As a result, the study was successful in showcasing that loss aversion and ambiguity aversion are positively associated with dividend payouts. On the other hand, patient investors prefer lower dividend ratios. 


\section{Conclusions and Readership}

The following are some of the reasons why this book is highly recommended. First, the book content has a substantial correlation with the global differences in time and risk, referring to financial decision making and financial markets. The book mainly consists of published academic journals from the last decade alongside first-time published journals. Furthermore, the book's writing approaches and language are succinct and concise, allowing readers to grasp broad finance-related ideas at low effort. In addition, the book's structure is well built, clear, and easy to follow. Finally, the book's target audience is provided a great range of high quality, relevant, and inspiring research works. The book content can be tremendously beneficial to the following groups of readers. First, current or future students that are interested or have been studying finance-related courses. While providing a broad range of knowledge regarding international and cultural differences to students, all levels of financial scholars may find this book extremely helpful in doing their research. Second, policymakers and government officials all over the world can use this book as a reference since it has done an international-scale survey and deep analysis.

Thorsten Hens, Marc Oliver Rieger, and Mei Wang have provided us a useful textbook, especially for those who are intensively working in cultural and behavioral finance. The book is accessible and conveys both technical and practical perspectives that are obviously useful for application-oriented researchers and policy-makers in their decision making. Therefore, this book should be put on the shelf to broaden views.

Author Contributions: Conceptualization, T.L.D.H. and A.N.Q.H.; supervision, T.L.D.H.; project administration, T.L.D.H.; writing-review and editing, T.L.D.H. and A.N.Q.H.; funding acquisition T.L.D.H.; writing - original draft preparation, A.N.Q.H. All authors have read and agreed to the published version of the manuscript.

Funding: This research received no external funding.

Conflicts of Interest: The authors declare no conflict of interest.

\section{References}

Acharya, Viral V., Acharya Yakov Amihud, and Lubomir Litov. 2011. Creditor rights and corporate risk-taking. Journal of Financial Economics 102: 150-66. [CrossRef]

Ariely, Dan, Joel Huber, and Klaus Wertenbroch. 2005. When do losses loom larger than gains. Journal of Marketing Research 42: 134-38. [CrossRef]

Barberis, Nicholas, and Ming Huang. 2006. The Loss Aversion/Narrow Framing Approach to the Equity Premium Puzzle. Cambridge: National Bureau of Economic Research.

Barberis, Nicholas, and Ming Huang. 2008. The loss aversion/narrow framing approach to the stock market pricing and participation puzzles. In Handbook of the Equity Risk Premium. Edited by Rajnish Mehra. Amsterdam: Elsevier.

Barillas, Francisco, Lars Peter Hansen, and Thomas J. Sargent. 2009. Doubts or variability? Journal of Economic Theory 144: 2388-418. [CrossRef]

Benartzi, Shlomo, and Richard H. Thaler. 1995. Myopic Loss Aversion and the Equity Premium Puzzle. The Quarterly Journal of Economics 110: 73-92. [CrossRef]

Breuer, Wolfgang, M. Oliver Riegerb, and K. Can Soypaka. 2012. The behavioral foundations of corporate dividend policy: A cross-country empirical analysis. Journal of Banking and Finance 42: 247-65. [CrossRef]

Brockman, Paul, and Emre Unlu. 2009. Dividend policy, creditor rights, and the agency costs of debt. Journal of Financial Economics 92: 276-99. [CrossRef]

Camerer, Colin F. 2000. Prospect Theory in the wild: Evidence from the field. In Choices, Values, and Frames. Edited by Daniel Kahneman and Amos Tversky. Cambridge: Cambridge University Press and the Russel Sage Foundation, pp. 288-300.

Camerer, Colin F. 2005. Three cheers-Psychological, theoretical, empirical-For loss aversion. Journal of Marketing Research 422: 129-33. [CrossRef]

Chen, Zengjing, and Larry Epstein. 2003. Ambiguity, risk, and asset returns in continuous time. Econometrica 70: 1403-43. [CrossRef]

De Martino, Benedetto, Colin F. Camerer, and Ralph Adolphs. 2010. Amygdala damage eliminates monetary loss aversion. Proceedings of the National Academy of Sciences of the United States of America 1078: 3788-92. [CrossRef]

Deole, Sumit, and Marc O. Rieger. 2020. Risk, Time and Migration. Working Paper. Trier: University of Trier.

Drobetz, Wolfgang, Matthias C. Grüninger, and Simone Hirschvogl. 2010. Information Asymmetry and the Value of Cash. Journal of Banking and Finance 34: 2168-84. [CrossRef]

Eagly, Alice H. 1987. Sex Differences in Social Behavior: A Social-Role Interpretation. Mahwah: Lawrence Erlbaum Associates, Inc. 
Falk, Armin, and Johannes Hermle. 2018. Relationship of gender differences in preferences to economic development and gender equality. Science 362: 6412. [CrossRef]

Frederick, Shane, George Loewenstein, and Ted O'donoghue. 2002. Time discounting and time preference: A critical review. Journal of Economic Literature 40: 350-401.

Gollier, Christian. 2011. Portfolio choices and asset prices: The comparative statics of ambiguity aversion. The Review of Economic Studies 78: 1329-44. [CrossRef]

Hardelauf, Marie. 2019. Gender Differences in Investment Behaviour across Countries and Their Relationship to Economic Development. SSRN Working Paper. [CrossRef]

Hofstede, Geert. 1991. The confucius connection: From cultural roots to economic growth. Organization Dynamics 164: 4-18. [CrossRef]

Kahneman, Daniel, and Amos Tversky. 1979. Prospect Theory: An Analysis of Decision under Risk. Econometrica 47: 263-91. [CrossRef]

Lerner, Jennifer S., Deborah A. Small, and George Loewenstein. 2004. Heart strings and purse strings: Carryover effects of emotions on economic decisions. Psychological Science 15: 337-41. [CrossRef]

Mehra, Rajnish, and Edward C. Prescott. 1985. The equity premium: A puzzle. Journal of Monetary Economics 15: 145-61. [CrossRef]

Novemsky, Nathan, and Daniel Kahneman. 2005. How do intentions affect loss aversion? Journal of Marketing Research 422: 139-40. [CrossRef]

Rieger, Marc Oliver, and Mei Wang. 2012. Can ambiguity aversion solve the equity premium puzzle? Survey evidence from international data. Finance Research Letters 92: 63-72. [CrossRef]

Schmidt, Ulrich, and Stefan Traub. 2002. An experimental test of loss aversion. Journal of Risk and Uncertainty 253: 233-49. [CrossRef]

Sokol-Hessner, Peter, Ming Hsu, Nina G. Curley, Mauricio R. Delgado, Colin F. Camerer, and Elizabeth A. Phelps. 2009. Thinking like a trader selectively reduces individuals' loss aversion. Proceedings of the National Academy of Sciences of the United States of America 10613: 5035-40. [CrossRef] [PubMed]

Tanaka, Tomomi, Colin F. Camerer, and Quang Nguyen. 2010. Risk and time preferences: Linking experimental and household survey data from Vietnam. American Economic Review 1001: 557-71. [CrossRef]

Vendrik, Maarten C. M., and Geert B. Woltjer. 2007. Happiness and loss aversion: Is utility concave or convex in relative income? Journal of Public Economics 91: 1423-48. [CrossRef]

Wang, Mei, Marc Oliver Rieger, and Thorsten Hens. 2016. How time preferences differ: Evidence from 53 countries. Journal of Economic Psychology 52: 115-35. [CrossRef] 